\title{
Access to Culture in the Digital Environment: Active Users, Re-use and Cultural Policy Issues
}

\author{
Aleksandra Uzelac* \\ Nina Obuljen Koržinek ${ }^{* *}$ \\ Jaka Primorac ${ }^{* * *}$
}

\section{SUMMARY}

Access issues have been placed in cultural policy focus with the aim to contribute to cultural development, social inclusion, quality of life, etc. and the digital domain opportunities have been looked at as a way to ensure delivering content to interested users. The issue of access to culture in the digital context is understood in terms of reducing obstacles, as well as, fostering opportunities. The concept is understood as the dynamic and social process and not a simple oneoff act of provision. This article outlines the challenges brought about for access to culture in the digital era and addresses policy frameworks concerning: a) the role of users and their participation opportunities and b) regulatory issues such as intellectual property rights (IPR) and re-use policies that enable or limit what kind of services cultural sector can offer in the digital domain. The article analyses both explicit and implicit policy approaches to regulating digital culture, as both remain relevant in ensuring that cultural content reaches its intended users. This provides the background for the investigation of the results

\footnotetext{
*Aleksandra Uzelac, Ph.D., Senior Research Associate, Institute for Development and International Relations (IRMO), Department for Culture and Communication, Zagreb E-mail: auzelac@irmo.hr

** Nina Obuljen Koržinek, Ph.D., Research Associate, Institute for Development and International Relations (IRMO), Department for Culture and Communication, Zagreb E-mail: nina@irmo.hr

*** Jaka Primorac, Ph.D., Research Associate, Institute for Development and International Relations (IRMO), Department for Culture and Communication, Zagreb E-mail: jaka@irmo.hr
} 
Medij. istraž. (god. 22, br. 1) 2016. (87-113)

obtained through the comparative policy analysis executed in the project 'Access to Culture. Policy Analysis' where different policy approaches to digital access in six selected countries (Austria, Croatia, Norway, Spain, Sweden and Turkey) are presented and interpreted. This is done with the aim to provide better understanding of the digital access issues that have to be taken into account in effective policy making for the inclusive and open digital culture.

Key words: access to culture, users participation, digital culture, cultural policy, public policy

\section{Introductory remarks}

Ever since the seventies and the adoption of the UNESCO Recommendation on Participation by the People at Large in Cultural Life and their Contribution to It (UNESCO 1976) different cultural policy documents refer to the access to culture as an essential right of all citizens. In recent years, the European policy debates on principles, commitments and practices of fostering access to culture have intensified and a number of policy documents have been adopted (European Commission 2007; Council of the European Union 2007a, 2007b, 2010a, 2010b, 2010c, 2012). Furthermore, different reports and policy papers have been commissioned investigating and elaborating on the new approaches to engaging audiences in digital environment (Righolt, 2015; Saldanha et al, 2015). In this article the approach to the digital access to culture will be examined in the context of European cultural policy agendas towards the inclusive digital culture, where the concept of access to culture is defined as 'a loosely defined set of policy rationales (e.g. development, social inclusion, human rights, etc.) through a number of key areas (e.g. heritage, digitalization, tourism, education, mobility, media literacy, etc.) and whose policy goals are to be achieved by specific policy instruments (e.g. policy coordination and reporting, improved monitoring, awareness raising, etc).' (Primorac, et al. 2015). Hereby we take into the account different conceptualisations of culture that focus either on its intrinsic or instrumental values (Holden, 2004, Throsby, 2010); concept of information as a non-rival good (Benkler, 2006); concept of communication that 'refers to a process of sharing, making common or creating a community' (Hamelink, 2003); and concept of culture as a collective memory that is 'dependent on communication for its creation, extension, evolution and preservation' (Foresta et. al., 1995).Through our analysis we are questioning if cultural policy agendas have been successful in developing instruments that ensure preservation of cultural memory in digital context, in maintaining balance between commercial and public interest of culture, and if users' rights to obtain and share knowledge and engage with creation, curation, and aggregation of content have been taken on board in digitisation agendas. 
Access to culture in the digital environment: active users, re-use and cultural policy...

Our research focuses on how the issue of digital access to cultural heritage has been conceptualised and implemented in cultural policy agendas through different instruments and legal mechanisms which either enable or impede wide cultural accessibility of existing digital cultural resources. Through the comparative policy analysis we investigated the European and national dimensions of digital access to culture and analysed and compared the implementation of the policies on digital access to culture in different national contexts ${ }^{2}$. In our analysis we firstly address the challenges of the digital era and investigate approaches to what does digital access mean in the context of intellectual property rights (IPR). There we are taking on board issues of re-use and the role of users and their real participation opportunities, with aim to provide better understanding of the digital access issues that have to be taken into account in effective policy making for the inclusive and open digital culture. Secondly, we present different policy approaches to digital access to culture in six selected countries (Austria, Croatia, Norway, Spain, Sweden and Turkey) in order to see the prevailing trends on the European level.

\section{Access to culture and challenges of the digital era for cultural policy making}

The right to obtain and share knowledge and the right to create and re-create are central to survival of any culture. Benkler draws our attention to the fact that information is both input and output in its own production process and he describes information as a non-rival good, meaning 'its consumption by one person does not make it any less available for consumption by another' (Benkler, 2006: 36). This means that information does not get 'spent' in communication with others, but it gets sustained and 'preserved', making both information and communication important parts of society's cultural fabric (Uzelac, 2008). The cultural heritage institutions, being custodians and communicators of our recorded cultural memory are looking for suitable models through which content in their safekeeping can be made available to audiences. They should be able to appropriate this content and use the related references in their communication and creative processes, thus sustaining our cultural memory and relating it to living cultures.

Being understood in terms of reducing relevant obstacles (physical, financial, social or psychological), as well as, fostering opportunities, the issue of access to culture forms part of the broader reflection on the importance of culture in the society. It has been placed in the cultural policy focus with the aim to contribute to cultural development, social inclusion, quality of life, democratisation of culture, human rights, etc. Analogue and digital domains have been looked at as ways to ensure delivering content to interested users, and it has been understood that '[a]ccess rests on the 
dynamic and social process, not a one-off act of provision' (Russo, et al., 2009: 154). Cultural institutions are looking for ways to reconcile their traditional mandates - providing access to our common heritage and preserve it for future generations with opportunities, as well as, challenges emerging in the digital era. They are emphasizing the relevance of the cultural content that they have in their safekeeping, for which they make effort to digitize in order to preserve it and easily communicate to users. Still, ensuring that digitised content reaches its intended users is not a straightforward and easy task and different policies are shaping the context in which cultural sector is developing its access models.

Access related policies have been understood as 'fostering processes, legal actions and institutions which promote cultural accessibility, as well as enhancing and supporting artistic, ethnic, sociolinguistic, literary and other expressions or heritage in a specific territory' (De Milano and Righolt, 2015). In addition to explicit or nominal cultural policies which are explicitly labelled as cultural, Ahearne (2009) points out the importance of implicit or effective cultural policies which are not labelled as cultural but have a profound impact on the field of culture. They include those 'deliberate courses of action intended to shape cultures but which are not expressly thematised as such', as well as, various 'unintended cultural side effects of various policies' (Ahearne, 2009: 144). Concerning digital access issues, explicit cultural policies mainly address issues of audience engagement via digital means, while overall digital culture development is very much affected and shaped with such implicit policies. For example, communication and media policies look at access and participation in the wider context where issues such as equity of access, concentration trends and net-neutrality shape the models for our wider communication activities and have strong implications for fundamental freedoms and democracy, including freedom of expression, thus representing a potential mobilising tools for policy-making.

When considering the digital access issues and relevant policy measures and instruments, researchers have initially placed focus on general connectivity and providing access infrastructure, but in recent years real participation opportunities for users and their required skills and competences have been taken into account as well. This includes reflection on the correlation between policies and practices shaping digital culture and digital access issues (Frau-Meigs, 2013; Uzelac, 2004, 2008). In the digital domain, access to culture issues are placed in wider framework of ensuring balance between commercial and public interest and ensuring a full engagement of active users with creation, curation, and aggregation of content and ensuring their right to obtain and share knowledge. Thus, issues related to copyright and open access present relevant framework for considering access to culture in the digital domain. Current debates include those advocating for the promotion of openness and participation and others that seek restrictions and centralised control (Edwards at 
Access to culture in the digital environment: active users, re-use and cultural policy...

al., 2015). In order to address issues of cultural and societal reach, as well as fundamental rights and freedoms in the context of digital culture, policy principles need to consider issues of curation, equity of access, openness, participation and accountability. Frau-Meigs (2013: 13) stresses that ' ...those freedoms and values are tested against issues of content pricing, data protection and privacy, intellectual property rights and the creative and civic agency of users (including amateur professional and "piracy" practices)'.

A significant impact on access to digital culture has been made by the restrictions due to the intellectual property rights, affecting the role and services of museums, archives and libraries in the digital era. They are voicing their concerns and asking for policy solutions that would foresee what is coming and that would ensure that heritage and the values they defend are transposed to the digitally networked cultures. The heritage sector is concerned that, unless cultural policies recognise that the access to culture is a fundamental aspect of our cultural memory and ensure that the ways are found to stimulate the online accessibility of the copyrighted material, a significant part of our more recent culture will not be available for users.

In the European context, the Digital Agenda for Europe (DAE) (European Commission, 2010) describes a complex framework within which the development of online services and opening up of cultural content should be looked at. It cuts across the regulatory frameworks that used to be treated separately - from digital single market and cybercrime to privacy, digital literacy and digitizing the cultural heritage in the EU. Within this Agenda, the opening up of access to content is listed as contributing towards a vibrant European digital single market. Europeana is listed in this strategy as a flagship EU cultural project, aggregating content from cultural heritage collections, bringing benefits to EU society through smart use of ICT and revealing information that promotes cultural diversity, creative content and accessibility of European cultural heritage online. Whilst the Digital Agenda approach emphasises the 'supply side' of cultural content provision, approaching issues related to cultural diversity from the distribution point of view where 'more content can reach more people', it leaves the cultural sector free to approach a 'demand side' and focus on users and their habits that also play a significant role in achieving success within the digital space.

Explicit and implicit cultural policies, both at national and EU levels, remain relevant in ensuring that cultural content reaches its intended users. In the continuation of the article audience engagement approaches and regulatory issues such as IPR and re-use policies that are relevant for ensuring access to digital content will be addressed. This provides the background for the analysis of the status of the digital access to culture in six countries (Austria, Croatia, Norway, Spain, Sweden and Turkey) that will be presented in the continuation of the article. 
Medij. istraž. (god. 22, br. 1) 2016. (87-113)

\section{Cultural sector's strategies for reaching users}

The ways citizens consume, share and create cultural content have changed. When considering digital access issues, cultural strategies are mostly focussing on the digitisation of heritage and the audience engagement. Today over $78 \%$ of the EU citizens regularly engage in communication in a digital context (Internet World Stats, 30 June 2015), turning to digital platforms to search for information, communicate, share, contribute to joint projects, shop or enjoy entertainment activities. Traditional cultural institutions, as important enablers of access to cultural services, are faced with the need to recognise and support new ways through which cultural audiences today enter the cultural experience occurring in the online environment and mainly outside of the cultural sector virtual resources. They need to hold onto a clear understanding of what they are trying to do in digital context and for whom. Ensuring visibility in the digital domain, where cultural organisations have found themselves in a situation where they must compete for users' attention, demands for an active approach. In trying to ensure that cultural heritage and knowledge related to it do not stay locked in the archives of cultural institutions, cultural sector has begun to consider making their content available through social networks, photo or video sharing sites, etc. The cultural sector has started to recognise that the supply logic is not sufficient anymore and it has begun to consider the importance of the demand side and the focus on users, their habits, expectations and tastes that also play a significant role in achieving the success in digital space. What users do and how they interact with the available cultural content, to whom do they trust, where do they look for information, which niches can be spotted and similar questions are guiding reflection on the effects of specific strategies. Having a clear understanding of what an organisation is trying to do, for which audience and which values drive its actions, creates a grid against which online digital metrics should be set. Still many countries fail to undertake on a regular basis studies and national surveys on audience engagement trends in digital environment that would provide relevant insight for overall sector's activities and show if investments put in the online activities can be justified. ${ }^{3}$

The issue of access to culture in the digital context that is understood in terms of reducing obstacles, as well as, fostering opportunities, should provide users with more opportunities than just the right to see the displayed content on the websites of cultural institutions. The prevailing logic 'look but do not touch' does not provide for real participation opportunities for users and it does not sustain sharing cultural knowledge. In order to foster users' opportunities, digital access should encompass four key components to learning 'finding information and knowledge, doing something with it, sharing it with an audience and reflecting on it' (Russo, et al, 2009: 155). The existing digital environments with numerous different platforms and tools 
Access to culture in the digital environment: active users, re-use and cultural policy...

provide many opportunities for sharing cultural content online and we are speaking of the rise of 'participatory culture', prosumers and 'makers revolution' that allows users to take the available content and do something with it - repurpose it, mash it, remix it, produce new material, or make physical objects. However, in reality the users will need to invest significant time and effort in order to find what is useful to them and then check if the content is legally available for re-use and of the adequate quality, resolution, formats etc. To be useful to its users, the available cultural content needs to be in a form that is 'fit for its purpose' (Malde and Finnis, 2015). This addresses the issue of providing different platforms, products or services for different types of users (tourists, students, children, families, etc.), ensuring removing digital barriers for people with disabilities (Bachmeier, 2014), as well as making sure that digitised cultural content is useful and usable to users.

\section{IPR and use and re-use issues: is cultural sector ready for re-use?}

The issue of attracting users' attention is one relevant aspect of engaging audience, while one of the other relevant aspects relates to the rights that are given to the users regarding the use of digitised cultural content. Thus, IPR and rights of use and reuse enable or limit what kind of services cultural sector can offer in the digital domain. The dilemma between the implementation and improvement of the existing copyright rules and legislation, and/or a shift towards promotion of the open source models and approaches remains present in all aspects and forms of digital culture. The following part of the article presents approaches to the general copyright rules and policies as well as the re-use policies and practices.

At the EU level, the issue of re-use has been discussed and regulated in a wider framework of the Open Data Strategy (European Commission, 2011) and the Directive on Re-use of Public Sector Information (European Commission, 2003) - also called the 'PSI Directive' - that regulates re-use issue with the aim to stimulate a growing market in added-value products and services based on public sector information reuse. The cultural sector is expected to be a catalyst for creativity and contributing to EU economy and growth of jobs (European Commission, 2007), but until the revision of the PSI Directive in 2013 (European Commission, 2013), culture has not been included within the scope of the PSI Directive due to concerns expressed by the governments and public cultural institutions about cost related issues related to the clearance of IPR of third parties. In 2013, the revised PSI Directive included libraries, museums and archives in its scope. Member States have been given two years to transpose the provisions of the revised Directive into their national laws. The question is are they ready for re-use? 
In the digital context, in order to be findable and usable, cultural institutions need to release their material in a way that allows it to be readable by humans, as well as machines through metadata. Even if the problem of visibility is resolved and the target users are reached there still remains the issue of usefulness and usability of the available digital content. Cultural heritage digital collections store diverse materials and a high proportion of their holdings involves third-party rights and this imposes limits on what can be done with digitised collections (Dietrich and Pekel, 2012). Even though the public sector has been making a significant effort to make European digital content accessible in the past decade, the progress is rather slow. Some estimates suggest that some $20 \%$ of the European cultural content has been digitised, but only about one third of that digitised content (about 6\%) has been made publicly accessible online (Feijoo, et al., 2013:15). The barriers for distribution of public digital content in Europe range from lack of funding for digitisation, lack of maturity of appropriate business models, lack of adequate content rights management, to lack of appropriate skills within public institutions, and lack of user awareness on digital European heritage, etc. (Feijoo, et al., 2013: 146-148).

In addition to these barriers, the study reports that only $31 \%$ of cultural institutions have as yet an explicit policy regarding the use of digital collections, thus, authors claim that content is available but not useful (Feijoo, et al., 2013:116). Even those institutions that have clearly stated rights of use do not automatically enable re-use. According to the data about licences used at Europeana platform in 2014, Europeana has enabled access to over 36 million objects out of which 53\% does not allow for re-use, $14 \%$ allows for re-use with restrictions and $32 \%$ allows re-use with attribution of source 4 . This means that content under 'no re-use licence' cannot be legally shared, incorporated into various, blogs, Wikipedia and other websites, nor taken by users and applied in their creative processes. To achieve this open data licences are essential, as IP rights by default restrict the use of available content unless rights are cleared or if it is known that content is in public domain.

The so called 'Black hole of $20^{\text {th }}$ century' (Niggemann et al, 2011) has been recognised as an issue and impediment in providing access to the $20^{\text {th }}$ century art that still did not enter into public domain. Content belonging to the $20^{\text {th }}$ century culture (under copyright regime) is often not digital and frequently out of distribution in its analogue form. Digitising it and clearing all the IP rights related costs is cumbersome and expensive, as heritage institutions are often not the right holders of the objects that they keep in their collections. In addition, the orphan works ${ }^{6}$ present a barrier to mass digitisation projects or free reuse of such objects if digitised. 'The Association des Cinémathèques Européennes estimates that $21 \%$ of films held in audiovisual archives are orphaned, with $60 \%$ of these being over 60 years old. The British Library estimates that $40 \%$ of its in-copyright collections are orphan. 'In from the Cold' report estimated approximately $90 \%$ of the photographic record in 
Access to culture in the digital environment: active users, re-use and cultural policy...

UK cultural institutions as orphaned' (Niggemann et al, 2011: 16). The Directive on certain permitted uses of orphan works (European Commission, 2012) provides guidance on how to treat such works and what is permitted, but this still remains a complicated issue impeding digitisation of, access to and easy use of a significant part of the $20^{\text {th }}$ century culture.

Clearly, IPR framework influences largely what is accessible or not in the digital context and what services cultural institutions can provide to users. According to the analysis by Leonhard Dobusch of the European Commission's 'Report on the responses to the public consultation on the review of the EU copyright rules' the stakeholders are clearly divided in their opinions how well the EU copyright law meets the requirements of the digital environment. Citizens and institutional users think it is not adequate and needs to be reformed while authors and other right holders are convinced that it is good as it is, which indicates the unbalance of the current EU copyright. Thus we would agree with Dobusch when he stresses that the direction for copyright reform efforts of the new EU Commission should go towards rebalancing copyright that 'requires at least some reform as demanded by end users and institutional users, most importantly a more harmonized and flexible system of exceptions and limitations' (Dobusch, 2014).

IPR is clearly not the only business model used in the cultural sector. There are some good examples of open access business models such as the Rijksstudio in the Netherlands, launched in 2012, which represents a best practice example of open access to cultural heritage collections. It is a platform which presents over 125000 high resolution images of objects in the public domain that users can freely browse, share and download for their personal and commercial use ${ }^{7}$. There are more examples of projects working on the environments that would promote re-use, among which Europeana, (via its Europeana labs) is the most prominent. It promotes open source tools, organises creative challenges and hackatons to re-use available cultural content and offer it to users via different websites or smartphone apps. It also tries to develop platforms or examples of digital cultural products to foster accessible education, tourism and leisure that enable usability and accessibility of European cultural heritage. It advocates for the 'fit for purpose' logic that cultural institutions should apply when putting their content online in order to make it both accessible and usable (Europeana Foundation, 2014)

The Free Culture movement also revolves around the cooperative creation of culture, sharing and re-use, and promotes strategies that make cultural practices sustainable and that empower society. Embracing the logic of abundance, on which Free Culture is based, could provide the cultural sector with new ways of achieving its long-term goals if cultural policies would ensure that the existing (IPR) frameworks do not interfere with or limit the development of initiatives based on Free Culture principles and logic of open access and sharing. 


\section{Six national cases on ensuring digital access to culture}

In order to address policy frameworks related to digital access to culture in more detail, in this part we will present the results obtained through policy analysis from six countries (Austria, Croatia, Norway, Spain, Sweden, and Turkey). Following the adopted approach of using four levels of the analysis of policy discourse through the „polity-politics-policy-practice“ (PPPP) research framework, the comparative analysis of the country case studies has been undertaken. The research included the analysis of relevant legislation, policy and strategic documents and action plans, as well as other statistical and secondary data. The six detailed national reports are included in Access to culture - policy analysis: final report (EDUCULT (ed.), 2015) that analysed the cultural policy provisions for ensuring access to culture and various transversal aspects of the participation, including also digital access. In the short case descriptions presented below we will assess how the issues of digital access have been conceptualised and developed through studied national policy instruments and practice. The data collected in the above-mentioned research has been complemented with additional information gathered through the Compendium of Cultural Policies and Trends in Europe, a web-based and permanently updated information and monitoring system of national cultural policies in Europe ${ }^{8}$. The research results show that in all the researched countries ICT has become a tool in the daily work of cultural institutions and that digitisation of cultural heritage has been present on their national cultural policy agendas. However, their digitisation strategies reflect values set in other socially oriented strategies and these differ among analysed countries that shall be highlighted in the continuation of this chapter.

\section{Austria}

Austrian cultural policy recognises cultural pluralism, intercultural dialogue and diversity issues to be its important elements and considers that access to culture should take into consideration Austrian citizens with immigrant background (Educult, 2015: 140-164). The digitalization of cultural heritage collections has been on the Austrian cultural policy agenda since 2006 with expectations that this will contribute to a wider access to Austrian cultural goods. Technical conditions for the development of digital culture exist, as Internet has been widely spread - the Internet penetration rate for households in 2014 was 86,8\% (Internet World Statistics, 30 June, 2014).

Among documents relevant for digital access to culture is the eFit21 Digital Agenda for Education, the Arts and Culture (BMUKK, 2012) that aims at the efficient, sustainable and systematic utilisation of modern information and communications 
Access to culture in the digital environment: active users, re-use and cultural policy...

technology in the fields of education, arts and culture. It points that Austria's artistic and cultural heritage should be presented in an up-to-date way regardless of location, conveyed and preserved for future generations (Ratzenböck and Lungstraß, 2014). In order to ensure the archiving and availability of data on Austrian culture, the Austrian central platform Kulturpool, offers central access to digitalised Austrian cultural heritage resources in museums, libraries and archives, while the image databases Artothek and the Fotosammlung host comprehensive digital holdings of art and photography of the Federal Government. (Ratzenböck and Lungstraß, 2014) Even though the above mentioned platforms provide an overview of the Austrian digital collections, there is still no strategy in place for using the digital resources for new audiences or target groups. This has been left to the cultural institutions to develop individually. Thus the usage of social media and digital data for the provision of access to culture has been in focus of discussions for cultural professionals. It has been recognised that 'social media plays a big role for cultural institutions to interact with the young audience, to make awareness about their events and programs' (Educult, 2015: 162). The attempt to reach younger audiences has been done through MUSEUM ONLINE programme that aims at the active involvement of the students (10 to 19 years old) with the art and culture content and with the cultural institution functioning as their project partner, combining participatory approach, access to culture, and the technical and cultural use of ICT.

\section{Croatia}

To make culture accessible to all citizens is a basic goal of today's contemporary cultural policy of Croatia (Primorac and Obuljen Koržinek, 2015: 165-220) that has persisted as basic policy logic ever since the socialist period. In Croatia $70,9 \%$ of population had access to Internet in 2014 (Internet World Statistics, 30 June, 2014) and Croatian cultural policies have been addressing the challenges of the digital era by the efforts to reform its media and cultural system. The Strategic Plan of the Ministry of Culture that focuses on articulation of existing policies and programmes and the National Strategic Programme for Audiovisual Industry are two recent policy documents indicating cultural policy shift in approaching access to culture. The National Strategic Programme for Audiovisual Industry set a number of new goals for improving access and participation, including the project of digitalisation of independent cinemas across the country that showed its first results in 2013 with digitisation of 28 cinema halls and six film festivals in 18 counties and in 27 cities. This resulted in increased participation and broadening film audiences in a number of smaller cities that did not even have cinemas (Primorac and Obuljen Koržinek, 2015: 192). In 2008, the Croatian government proclaimed the digitalisation of television broadcasting as a matter of national interest, aiming at 'creating conditions 
for quality improvement in the scope of production and broadcasting of content that would enrich the media space' (Primorac and Obuljen Koržinek, 2015: 194).

The Strategic Plan of the Ministry of Culture stresses as one of its aims the increased availability of the cultural heritage in digital arena, aimed at general public that should be achieved through specific digitalization projects. However, even in 2015, Croatia still does not have the official Strategy of Digitalization of Cultural Heritage that is a significant obstacle for development of digital culture. Presently, the budget for digitisation activities is modest and most activities that are being financed by the Ministry of Culture are fragmented and not coordinated. 'Digitisation is still approached mainly through digitising of catalogues, and other data available in i.e. museums, libraries, etc., but rarely in the application of other possibilities that these processes bring.' (Primorac and Obuljen Koržinek, 2015: 204) This resulted in many small scale digitisation activities undertaken by different museums, libraries and archives, presenting their digitised content on their institutions' web pages, which is not particularly user friendly and does not contribute to higher visibility of the digital cultural heritage. The use licences are usually quite restrictive not allowing reuse without clearing rights first and there is no national digital platform through such digitised heritage would be accessible at one place and easily searchable. Croatian cultural content is also very modestly represented in Europeana where in January 2015 less than 7000 digital objects from Croatian cultural institutions could be accessed, all with no reuse licence that does not provide users with any participation possibilities beyond merely looking at the exhibited digital objects. In Croatia, studies and surveys on audience engagement trends in digital environment are lacking. Cultural institutions rarely commission and/or conduct the research specifically oriented to the audience analysis and 'there is a pressing need to improve the national statistics in order to be able to analyse the results of specific policies and programmes as well as to develop measurable and comparable indicators including those on the access and participation' (Primorac and Obuljen Koržinek, 2015: 205)

\section{Norway}

From the National report of Norway (Hylland, 2015: 221-260) it is clear that the welfare state ideology is still the main principle guiding the Norwegian cultural policy that puts a considerable emphasis on the democratisation of culture. A fundamental goal for Norwegian cultural policy is that the whole population shall have access to cultural goods, ensuring citizens the right to participate in culture, and maintaining equality. The White paper on culture (Norwegian Ministry of Culture, 2003) places emphasis on the need for a concept of culture to be sufficiently open to the changes of society and it maintains that globalisation and individualisation re- 
Access to culture in the digital environment: active users, re-use and cultural policy...

quire a concept of culture that can cope with the diversity and complexity of contemporary culture.

In Norway, the general digital literacy rate is quite high, and the latest Media Barometer from Statistics Norway shows that $85 \%$ of the population uses Internet on a daily basis (Hylland, 2015: 255), while $95,1 \%$ of the population has access to the Internet from their home (Internet World Statistics, $30^{\text {th }}$ of June 2014). The report identifies different policy papers that address issue of digital access. The White paper on libraries (Norwegian Ministry of Culture, 2009) describes new roles for libraries in a modern, digital age, emphasising the importance of the concept of knowledge commons for the access to knowledge and culture in digital context, stating as its main objective, the need 'to ensure that all have access to art and cultural experiences and opportunities to express themselves through art and culture, independent of geography or economic and social divisions' (Hylland, 2015: 242).

The White paper on digitisation of cultural heritage (Norwegian Ministry of Culture, 2009a) tackles the digitisation as a topic for cultural policy and particularly access policy in a globalized and digital cultural market, acknowledging both opportunities and challenges that digitisation creates for public cultural policies. It recognises opportunities for cultural heritage sector where digital technologies help to break down the barriers between sectors and institutions, strengthening users' access to sources, thus providing new opportunities for dissemination and access services of the heritage sector. 'From a dissemination and user perspective, the main objective is to enable cultural heritage institutions, within the bounds of legislation and regulations, to make available in digital form as much as possible of the source material entrusted to these institutions.' As a prime objective of the digitisation efforts it recognises the need 'to make sources of culture and knowledge more readily accessible to users' (Hylland, 2015: 242).

The digitisation as a tool for (cultural) democracy has played the important role within the field of cultural heritage. The initiatives of creative use of digital data that have been launched in the cultural heritage sector "where heritage institutions and public authorities (e.g. Arts Council) have encouraged the inclusion of information and stories from the general public in databases on cultural heritage' (Hylland, 2015: 258). On a cultural industries side, the report states that 'Cultural policy documents and measures acknowledge to a large degree that the use of e.g. music has been digitized, but the public policy role in this plays a very small role. In accordance with the characteristics of different art forms and sectors, the tools of access also varied. For example, digitisation plays a significant role in the public debate on literature policy, but for the performing arts' sector, the topic seems almost completely absent, while music has been digitized but the public policy there plays a small role' (Hylland, 2015: 256). 
Medij. istraž. (god. 22, br. 1) 2016. (87-113)

\section{Spain}

The Spanish national report (Interarts, 2015: 261-296) identifies pluralism, creativity and innovation, reorganization of the administrative organizations, education, participation and cultural heritage among the main priorities of Spanish cultural policy. The report states that universal right of access to the culture is considered as one of the prerequisites of the construction of a more equal and participatory society. Digital access issues are tackled in The General Strategic Plan 2013-2015 of the State Secretary for Culture, that amongst its core objectives lists the articulation of a policy that guarantees the right of access to culture and contributes to underpinning citizenship and social cohesion, and the promotion of creation, innovation and knowledge production and where the support to culture on the Internet by safeguarding the rights derived from intellectual property is highlighted. Within the framework of the 2011-2015 Strategy of the Plan Avanza 2, the government launched the Plan for the Promotion of the Digital Content Industry aiming to gain benefits from the creative potential of the sector and promoting innovation in all areas (Villarroya and Ateca-Amestoy, 2015). The Spanish Government increasingly encourages the legal supply of cultural content on the Internet which leads to the importance of clarifying the limits of intellectual property rights, especially in the digital environment ${ }^{9}$.

Recognising the relevance of new patterns of consumption, needs and demands of the young population, the 'importance of knowledge, promotion, visibility and use of new information and communication technologies, including digitalization of cultural content, for the purpose of increasing the access of young people to culture' (Interarts, 2015: 290) has been recognised as an issue that the cultural policy cannot overlook. In order to assess the developments in the area of digital culture, the Spanish Public Agency for Cultural Action (AC/E) since 2014 publishes an Annual Report on Digital Culture (Villarroya and Ateca-Amestoy, 2015).

Although in Spain the Internet penetration rate was $74.8 \%$ according to the Internet World Statistics ( $30^{\text {th }}$ of June 2014), 'Spain still needs to achieve a better geographical balance for development of access to digital resources by using specialized plans, in accordance with those adopted by the European Council in Lisbon in March 2000, to increase the level of cultural content within the new applications and to improve coordination between the national strategies designed by the various ministries involved and those drawn up regional communities and local councils.' (Interarts, 2015: 292-293) In order to redress the stated imbalance and boost the development of digital projects in culture that have been recognised as the emerging forms of access and participation, opportunities brought about by digitisation and the new technologies have been considered in the design of various programs by both public and private initiatives focusing on organizing projects (e.g. festivals, 
Access to culture in the digital environment: active users, re-use and cultural policy...

conferences and meetings) that bring into the focus the relationship between artistic creation and the new technologies.

\section{Sweden}

Swedish country case study indicates that many of Swedish cultural policy priorities relate to access to culture (references are made to children and young people's access to culture; access to culture for seniors and people with disabilities; criteria of gender equality; cultural diversity and social integration; regional and local cultural strategies; and accessibility of digital data) (Jonsson Malm and Hansen, 2015: 297360 ). In addition, education on all levels (including digital) is the mayor government priority for the development of information society (Harding, 2015). The infrastructure for digital access is well developed $-94,8 \%$ of the Swedes have access to the Internet from their homes (Internet World Statistics, $30^{\text {th }}$ of June 2014). This is also reflected in use of the Internet for cultural purposes: 'Between 60 and 80 percent of the Swedish people use the Internet to read newspaper articles, search for information on cultural products and events, listening to radio and music, and watch streamed movies and TV shows. Hence, the digital divide (i.e. inequality in access to digital resources) seems to be very small in Sweden' (Jonsson Malm and Hansen, 2015: 340-341). Digitisation has been recognised as one of the biggest trends influencing the governance of access to culture, which offers new methods of preservation and new ways to communicate arts and culture to a wider public. The report states that 'the technology has given rise to new patterns of consumption with new needs and demands, new behaviour patterns and new attitudes' and that 'the overall objective of digitisation is that cultural activities, collections and archives to a larger extent should be digitally preserved and made available electronically to the public. All governmental agencies that collect, preserve and provide cultural heritage must by 2015 have guidelines on access and prioritization' (Jonsson Malm and Hansen, 2015: 329). Thus, there have been several changes in regulations and practices, including copyright issue and measures were proposed against illegal sharing and downloading of copyright protected materials, based on EU Directive IPRED (International Property Right Enforcement Directive) (Harding, 2015).

The research data shows that Sweden approaches this issue systematically. Since 2011, the National Archives is responsible for establishing a coordinating secretariat for the digitisation of cultural heritage. Swedish secretariat for national coordination of digitisation, digital preservation and digital access to cultural heritage (Digisam) is responsible for a strategy aimed at cultural heritage preservation called The Digit@l Cultural Heritage (Digit@lt kulturarv). Digisam oversees the development work and capacity building in relation to digitisation issues and its priorities 
are digitisation of cultural heritage, movie theatres, and Swedish movies. In addition to Digisam work, the Swedish Arts Council has responsibility for evaluating the digitisation of performing arts and how digital technology can be used to make culture more accessible to people with disabilities. Swedish disability policies also include requirements for all institutions that receive financial support from The Swedish Arts Council and The National Heritage Board to ensure barrier free access for people with disabilities that includes deadlines for developing action plans, removing obstacles and that also extends to cultural institutions' websites and e-services (Jonsson Malm and Hansen, 2015: 327).

Different types of cultural institutions are facing diverse challenges and have chosen different strategies to foster access to culture. As currently only $3 \%$ of the overall archival collection is available in the digital form, for Swedish National Archives main priority is the digitisation of their collections, focusing on digitisation of the most frequently used material. They established working process descriptions: Provide, Make Accessible, Make Digitally Accessible and Increase Knowledge as a framework for working methods and evaluating criteria for archives' digital activities. On the other hand, in the field of museums, e.g. Jamtli museum has one of the largest photo collections in the country (holding approximately 9 million negatives and glass plates) and their biggest investment in regard to new technology is the digitisation of the museum's large photography collection. Therefore, archives have focused mostly on access to their collections while the museums interpret access in a broader sense and are 'working in a more systematic and effective way with issues related to equality, inclusiveness and social cohesion' (Jonsson Malm and Hansen, 2015: 345).

From the Swedish report it is visible that Swedish cultural institutions have different approaches to digitisation, depending on what kind of cultural institution it is, what kind of activities they are engaged in, and how much resources they have. If they had the time and money 'it is probably safe to assume that most cultural organisations would have intensified their efforts in this area' (Jonsson Malm and Hansen, 2015: 344).

\section{Turkey}

Turkey has a centralised system of cultural policy and management and access to culture is not an explicitly mentioned policy area, but Ministry of Culture and Tourism has 'put in place mechanisms in order to improve infrastructure and delivery of cultural services that has direct bearing on the availability of culture' (Aksoy et al, 2015: 365). The use of new technologies, digitalization and the proliferation of technological advances is recognized as a priority and takes the form of various 
Access to culture in the digital environment: active users, re-use and cultural policy...

larger and smaller-scale programs that are realized in cooperation with different public actors. For example in 2012, Istanbul Development Agency funded a project focusing on digitisation which 'seeks to maximise the contribution of new technologies and communication material within the tourism sector and, thus, convert Istanbul to a competitive destination' (Aksoy, et al, 2015: 389). Similar projects are being undertaken across Turkey funded by Development Agencies offering three-dimensional tours in English, Turkish and Arabic for museums and heritage sites, as well as applications suitable for Android and Apple. Furthermore, the Directorate of Cultural Affairs Properties and Museums modernizes exhibition showcases in the museums and innovative techniques and technologies (e.g. interactive presentations, installations), are applied' (Aksoy, et al, 2015: 389)

In Turkey the Internet penetration rate in 2014 was 56.7\% (Internet World Statistics, $30^{\text {th }}$ of June 2014). In order to improve access to digitised resources, Ministry of Culture and Tourism undertook a project titled 'The Internet Access Centers' between 2005 and 2012 with the aim of providing internet access to low income families in public libraries. In order to foster a reading culture among children and the young population, the Ministry also ran an 'E-Library' project, offering free access to 200 titles on the E-Library website. Facilitating library access of visually impaired citizens by using digital means is another project integrating the new technologies into the libraries. All these initiatives help to modernise libraries and make them more accessible to different needs and socio-demographic groups. A similar focus can be seen with respect to many projects that aim at modernising museums and heritage sites through new technologies (participating in the Google Arts Project, 3-D visits providing access to remote visitors, improving cultural infrastructure by developing mobile apps or audio guides). Public-private partnerships are encouraged by Development Agency funding in order to improve projects development through the exchange of skills in IT, and digital education in schools around Turkey.

* * *

From the overview of the analysed country cases, it is visible that the most advanced approach to digital access can be found in Sweden and Norway, as in both countries digitisation efforts have been closely linked with access issues, as concerns for ensuring access lie in the core of their cultural policies. In these two countries the infrastructure for digital culture is the most advanced, and cultural policies have tackled this issue in the most systematic ways. Sharing a view that digitisation has played the important role within the field of cultural heritage and in making collections digitally accessible they focus on issues of open data and on clear description of the digitisation processes that will contribute to the real participation opportunities of their citizens. All the other analysed countries have a number of described 
programmes taking place in relation to digital access, but their policies have been less clearly articulated and their instruments less elaborated with the varied level of infrastructure for digital culture in researched countries. Even though the national reports have not gone in details regarding the re-use policies in the respective national contexts, all reports identify a copyright as a central issue for providing new digital services and cultural content online.

\section{Concluding remarks}

Wider participation in cultural life is an important concern of national cultural policies and, in that context, various digital opportunities have been explored focusing on those that promote access and participation of the citizens. The analysed cultural policies' discourses mostly understand access to culture as an essential right of all citizens, where it is equally important to provide model that ensures reducing relevant obstacles, as well as, foster opportunities of their citizens. This issue has been placed in the focus of cultural policies with the aim to contribute to the overall countries' cultural development, ensuring redistribution of public resources while catering for as wide segment of population as possible on one side, and promoting the idea of culture as a facilitator of social inclusion, ensuring the right of all individuals to take part in the cultural life of the community as a question of equal opportunities (De Milano and Righolt, 2015). However, different countries place their focus on different issues: for example, Austria and Spain place more emphasis on social inclusion and minorities, Sweden and Norway emphasise the importance of democratisation of culture and the overall quality of life that access to culture should ensure, Croatia is trying to overcome some transition and crisis related obstacles with its digitisation activities, and Turkey is trying to enhance its cultural tourism with the use of digital tools and ensure that access infrastructure exists to support different educational activities.

Taking into account the impact of relevant EU strategies and implicit and explicit policies, as well as the obstacles to use and re-use of digitised cultural contents, the analysis of the country reports shows that adequate business models are still being sought around Europe which is also confirmed by different studies, reports and policy papers. Online Access to Audiovisual Heritage Status Report warns that "we must be on top of the curve of evolution and try to foresee what is coming, to both keep making the content we 'host' ... relevant for the time we live and keep it accessible, retrievable, in short alive for future generations' (Verbruggen and Oomen, 2012: 6). The New Renaissance Report (Niggemann, et. al., 2011) proposes that '[i] nnovative business models, smart investments, collaboration between sectors (i.e. public-private, cultural-business, creative-technological), policies adapted to the needs of stakeholders (i.e. cultural institutions, creators, private partners, the gen- 
Access to culture in the digital environment: active users, re-use and cultural policy...

eral public) can help tackle the transition to the digital era in a dynamic and forward-looking way.' The adequate ways of achieving this are still being explored as transition depends on many issues and not all are within the scope of governance of explicit cultural policies.

Providing balance between commercial and public interest to ensure users' right to obtain and share knowledge and their engagement with creation, curation, and aggregation of content lies in the core of the digital culture and digital heritage. To achieve this it is essential to build an environment that would promote open access and re-use, ensuring that digital heritage gets communicated and used in citizens' communication and creative processes and sustained in our cultural memory. Benkler's (2006) notion of information as a non-rival good supports the importance of open knowledge sharing about culture that would constitute our future cultural heritage. Still cultural policies (particularly the implicit ones) contribute mainly to building more business like digital environment where users are catered for more as consumers and less as citizens. It should be reemphasized that access understood as the dynamic and social process and not a one-off act of provision (Russo et al., 2009: 154) contributes to the construction of citizens' key competences for creativity and social inclusion.

The digital environment has created 'conditions of possibility that suggest possible futures rather than determine them' (Hawk and Rieder, 2008: xviii). Thus, tapping into the opportunities offered by the digital context still depends largely on our existing explicit and implicit cultural policies and strategies that shape ways of working and acceptable models for arts and culture. In order to embrace the digitally infused context of today's society in which new practices, the convergence of art forms, issues of re-use, or open data could represent real opportunities for creative actors, cultural policies must be able to understand, support and regulate the changed cultural reality and accept and understand its practices. They need to find a way that goes beyond dichotomy: access versus revenue generation, or public value generation versus revenue generation. If creating an enabling environment for digital culture and for empowering citizens is set as a relevant cultural policy goal, then issues of long-term sustainability and viability of services should present themselves as relevant elements that cultural policies must address. The goal should be to ensure continuity for the cultural sector in which, open access is guaranteed, entrepreneurship is encouraged and artistic and cultural goals are supported and sustained by viable business models. It is clear that evidence-based policies are needed and they should be supported by systematic research and monitoring of issues and developments in digital culture, such as audience engagement, digitisation initiatives and financial models underpinning them, IPR, access and participation issues, criteria for evaluating success of institutions' digital activities, etc. We need to consider whether it is time for a paradigm shift in cultural policies. 


\section{ENDNOTES}

1 This research has been undertaken within the framework of 'Access to Culture. Policy Analysis' project whose aim was to further contribute to the ongoing EU access to culture policy debate, and to enable better understanding of ways through which EU programs and polices influence national access policies. The project was funded by the European Commission's Culture Programme in the period from May 2013 to April 2015 (grant number 2013-1384/001-001). The final report of the project that includes all the country case studies, is available as: EDUCULT (ed.), (2015), while research results for the Croatian case study are published in: Primorac, et al. (2015). The research included desk-based analysis of relevant legislation, governmental strategic policy documents and action plans, programmes of parliamentary political parties, campaign manifestos and available statistical and other secondary data that served as context for empirical part of research that included six country case studies. The country case studies were conducted by using the four levels of the analysis of policy discourse through the 'polity-politics-policy-practice' (PPPP) research framework levels that was developed so as to make further comparative research analysis of six country case studies (Austria, Croatia, Norway, Spain, Sweden and Turkey). The comparative policy analysis investigated the European and national dimensions of Access to Culture, analysing and comparing the implementation of the policies on access to culture in six countries (Austria, Croatia, Norway, Spain, Sweden and Turkey), trying to answer the questions related to what aims guide the Access to Culture policies and which instruments are employed. Selected transversal topics, such as, digitisation, cultural heritage, arts education, cultural democracy and social inclusion served as a background through which complexity of access related issues have been analysed.

2 The results of the research activities related to digital access to culture have been included in the chapter 'Digital Access: Sharing or Selling?' (Uzelac, et al., 2015) of the final report of the project 'Access to culture - policy analysis: final report' EDUCULT (ed.), (2015). This article further elaborates on information presented in the report's chapter.

3 In UK, however, a number of surveys and studies have been conducted providing cultural professionals with relevant insights for development of their digital activities, looking at behaviour, attitudes, spending patterns, barriers and future trends and providing some useful methodological points for arts and culture organisations in evaluating their own success in digitally engaging their audience (e.g. Arts Council of England, MLA and Arts\&Business, 2010; MTM, 2014; Finnis at al., 2011; Malde et al, 2014; Malde and Finnis, 2015).

4 Europeana Professional http://www.pro.europeana.eu/web/guest/content (accessed 19th January 2015).

5 This has been spotted while analysing the content available through Europeana, but it is true for cultural content on Internet in general.

6 Orphan works are works like books, newspaper and magazine articles and films that are still protected by copyright but whose authors or other right holders are not known or cannot be located or contacted to obtain copyright permissions. Orphan works are part of the collections held by European libraries that might remain untouched without common rules to make their digitisation and online display legally possible (European Commission, 2012).

7 Their approach has resulted in a successful model with downloads of 500000 images and the creation of over 180000 personal collections in Rijksstudio that encouraged Rijksmuseum to invite some living artists to give permission for the open access to their works as well (see more at www. rijksmuseum.nl/en/rijksstudio).

8 The comparative tables for all the countries involved are available at the following web address: http://www.culturalpolicies.net

9 Among its activities was the 2011 awareness raising activity for legal supply of cultural content on the Internet called 'Label Cultura en Positivo/Culture in Positive' (Villarroya and Ateca-Amestoy, 2015). 
Access to culture in the digital environment: active users, re-use and cultural policy...

\section{LITERATURE}

Aksoy, A. Kladou, S. \& Avetisyan, A. (2015) "National Report - Turkey" 361-423. In: Access to culture - policy analysis: final report. Vienna: EDUCULT. [online]. Available from: http://educult.at/wp-content/uploads/2013/04/Final_Report_Online_with-Annex.pdf [Accessed 21 September 2015]

Arts Council of England, MLA and Arts\&Business (2010) Digital audience: Engagement with arts and culture online. Available from: http://www.artscouncil. org.uk/media/uploads/doc/Digital_audiences_final.pdf [ㅅccessed 14 October 2015]

Bachmeier, C. (2014) "Barrier-free access to audiovisual content - a fundamental human right", IRIS plus, Strasbourg, 3.

Benkler, Y. (2006) The Wealth of Networks: how social production transforms markets and freedom. New Haven, London: Yale University Press.

BMUKK - Federal Ministry for Education, the Arts and Culture (2012) eFit21 Digital Agenda for Education, the Arts and Culture. Vienna: Federal Ministry for Education, the Arts and Culture. Available from: http://www.efit21.at/wp-content/uploads/2013/03/efit21_folder_en.pdf [Accessed 29 October 2015].

Council of the European Union (2007a) "Resolution of the Council of 16 November 2007 on a European Agenda for Culture", Official Journal of the European Union C 287, (4 pp). Available from: http://eur-lex.europa.eu/LexUriServ/LexUriServ.do?uri=CELEX:32007G1129\%2801\%29:EN:NOT [Accessed 12 February 2014].

Council of the European Union (2007b) Communication from the Commission to the European Parliament, the Council, the European Economic and Social Committee and the Committee of the Regions on a European agenda for culture in a globalising world, 10 May 2007. Available from: http://eur-lex.europa.eu/LexUriServ/LexUriServ.do?uri=COM:2007:0242:FIN:EN:PDF [Accessed 12 February 2014].

Council of the European Union (2010a) Council conclusions on access of young people to culture'. Available from: http://www.consilium.europa.eu/uedocs/ cms_Data/docs/pressdata/en/educ/117876.pdf [Accessed 12 February 2014].

Council of the European Union (2010b) Council conclusions on the role of culture in combating poverty and social exclusion. Available from: http://www.consilium.europa.eu/uedocs/cms_data/docs/pressdata/en/educ/117797.pdf [Accessed 11 February 2014].

Council of the European Union (2010c) European agenda for culture Working Group on developing synergies with education, especially arts education. Final 
Medij. istraž. (god. 22, br. 1) 2016. (87-113)

report. / editors Jean-Marc Lauret and Francois Marie. European Council Brussels. Available from:

http://www.artscouncil.ie/uploadedFiles/wwwartscouncilie/Content/News/Young people,_children, and_education/MOCedu_final_report_en.pdf [Accessed 19 October 2015].

Council of the European Union (2012) Report on policies and good practices in the public arts and in cultural institutions to promote better access to and wider participation in culture. Council of Europe - Brussels. Available from: http:// ec.europa.eu/culture/policy/strategic-framework/documents/omc-report-accessto-culture_en.pdf [Accessed 19 October 2015].

De Milano, C. \& Righolt, N. (2015) Mapping of practices in the EU Member States on promoting access to culture via digital means: EENC Report. Available from: http://www.eenc.info/wp-content/themes/kingsize/images/upload/MappingofpracticesintheEUMemberStates.pdf [Accessed 19 October 2015]

Dietrich, D. \& Pekel, J. (2012) Open Data in Cultural Heritage Institutions (European Public Sector Information Platform Topic Report No. 2012/04, Epsi Platform - Open Data in Cultural Heritage Institutions) [online]. Available from: http://www.epsiplatform.eu/sites/default/files/Final\%20TR\%20Open $\% 20$ Data\%20in\%20Cultural\%20Heritage\%20Institutions.pdf [Accessed 21 September 2015]

Dobusch L. (2014) EU Commission's Consultation Report Shows: Current Copyright is Unbalanced [online]. Available from: http://governancexborders.com/ 2014/07/25/eu-commissions-consultation-report-shows-current-copyright-isunbalanced/ [Accessed 21 September 2015]

EDUCULT (ed.) (2015) Access to culture - policy analysis: final report. Vienna: EDUCULT, 423 pp. [online]. Available from: http://educult.at/wp-content/uploads/2013/04/Final_Report_Online_with-Annex.pdf [Accessed 21 September 2015]

EDUCULT (2015) 'National Report - Austria' 140-164. In: Access to culture - policy analysis: final report. Vienna: EDUCULT. [online]. Available from: http:// educult.at/wp-content/uploads/2013/04/Final_Report_Online_with-Annex.pdf [Accessed 21 September 2015]

Edwards, L. \& Klein, B. \& Lee, D. \& Moss, G. \& Philip, F. (2015) "Discourse, justification and critique: towards a legitimate digital copyright regime?", International Journal of Cultural Policy, 21 (1) 60-77

European Commission (2003) DIRECTIVE 2003/98/EC OF THE EUROPEAN PARLIAMENT AND OF THE COUNCIL of 17 November 2003on the re-use of public sector information 
Access to culture in the digital environment: active users, re-use and cultural policy...

European Commission (2007) Communication from the Commission to the European Parliament, the Council, the European Economic and Social Committee and the Committee of the Regions on a European agenda for culture in a globalizing world. Brussels, $\operatorname{COM}(2007) 242$ final.

European Commission (2010) Communication from the Commision to the European Parliament, the Council, the European Economic and Social Committee and Committee of the regions A Digital Agenda for Europe. Brussels, COM(2010)245 final

European Commission (2011) Communication from the Commission to the European Parliament, the Council, the European Economic and Social Committee and the Committee of the regions Open data An engine for innovation, growth and transparent governance. Brussels, $\operatorname{COM}(2011) 882$ final

European Commission (2012) DIRECTIVE 2012/28/EU OF THE EUROPEAN PARLIAMENT AND OF THE COUNCIL of 25 October 2012 on certain permitted uses of orphan works OJ L299/5

European Commission (2013) DIRECTIVE 2013/37/EU OF THE EUROPEAN PARLIAMENT AND OF THE COUNCIL of 26 June 2013 amending Directive 2003/98/EC on the re-use of public sector information, OJ L175/1.

Europeana Foundation (2014) Europeana Strategy 2015-2020: 'We transform the world with culture', [online]. Available from: http://pro.europeana.eu/files/Europeana_Professional/Publications/Europeana\%20Strategy\%202020.pdf [Accessed 21 September 2015]

Feijoo, C. et al. (2013) Public and Commercial Models of Access in the Digital Era. European Parliament, (Directorate General for Internal Policies, Policy Department B, Structural and Cohesion Policies, Culture and Education), Strasbourg (211 pp.) Available from: http://www.europarl.europa.eu/committees/en/studiesdownload.html?languageDocument=EN\&file=93070 [Accessed 21 September 2015]

Finnis, J.; Chan, S.; Clements, R. (2011) Let's Get Real: How to Evaluate Online Success? [online]. Available from: http://weareculture24.org.uk/projects/actionresearch/how-to-evaluate-success-online/ [Accessed 21 September 2015]

Foresta, D., Mergier, A., Serexhe, B. (1995) The new space of communication, the interface with culture and artistic activities, Strasbourg, Council of Europe.

Frau-Meigs, D. (2013) Assessing the impact of digitisation on access to culture and creation, aggregation and curation of content, Background Paper for Governance of Culture - Promoting Access to Culture, Moscow 15-16 April 2013 (MinConfCult (2013) 5) [online]. Available from: https://www.coe.int/t/dg4/cultureheritage/culture/digitisation/MinConfCult2013_5Meigs-EN\%20def.pdf [Accessed 21 September 2015] 
Medij. istraž. (god. 22, br. 1) 2016. (87-113)

Hamelink, C. (2003) "Human Rights for the Information Society". In Girard B., Ó Siochrú S. (eds): Communicating in the Information Society. Geneva, UNRISD (United Nations Research Institute for Social Development). Available from: http://www.unrisd.org/unrisd/website/document.nsf/(httpPublications)/5DCA2 8E932BB8CFDC1256E240029A075?OpenDocument (last accessed October 2015)

Harding, T., 2015. Compendium of cultural policies and trends in Europe - Sweden. 17th edition 2015. Strasbourg: Council of Europe/ERICarts. Available from: http://www.culturalpolicies.net [Accessed 29 October 2015].

Hawk, B. and D. Rieder, (2008) “On Small Tech and Complex Ecologies”. In: Hawk B., Rieder D. M.; Oviedo, O. (eds): The Culture and Digital Tools. Minneapolis, London: University of Minnesota Press.

Holden, J. (2004) Capturing Cultural Value - How culture has become a tool of government policy. London, DEMOS. Available from: http:/www.demos.co.uk/ files/CapturingCulturalValue.pdf [Accessed 29 January 2016].

Hylland, O. M. (2015) "National Report - Norway", pp. 221-260. In: Access to culture - policy analysis: final report. Vienna: EDUCULT. [online]. Available from: http://educult.at/wp-content/uploads/2013/04/Final_Report_Online_withAnnex.pdf [Accessed 21 September 2015]

Interarts (2015) "National Report - Spain”, pp. 261-296. In: Access to culture policy analysis: final report. Vienna: EDUCULT. [online]. Available from: http://educult.at/wp-content/uploads/2013/04/Final_Report_Online_with-Annex.pdf [Accessed 21 September 2015]

Jonsson Malm, C. and A. Hansen (2015) “National Report - Sweden”, pp. 297-360. In: Access to culture - policy analysis: final report. Vienna: EDUCULT. [online]. Available from: http://educult.at/wp-content/uploads/2013/04/Final_Report Online_with-Annex.pdf [Accessed 21 September 2015]

Malde, S. et al. (2014) Let's Get Real 2: A Journey towards understanding and measuring digital engagement [online]. Available from: http://weareculture24. org.uk/projects/action-research/phase-2-digital-engagement/ [Accessed 21 September 2015]

Malde, S. and J. Finnis (2015) Let's Get Real 3: Is your content fit for purpose? [online]. Available from: http://weareculture24.org.uk/projects/action-research/ phase-3-fit-for-purpose/ [Accessed 21 September 2015]

MTM (2014) Digital Culture 2014: How arts and cultural organisations in England use technology [online]. Available from: http://artsdigitalrnd.org.uk/wp-content/ uploads/2014/12/Digital-Culture-2014-Research-Report2.pdf [Accessed 21 September 2015] 
Access to culture in the digital environment: active users, re-use and cultural policy...

Niggemann, E.; De Decker J.; Lévy M. (2011) The New Renaissance-Report of the 'Comité des Sages' Reflection Group on Bringing Europe's Cultural Heritage Online. Luxembourg: Publications Office of the European Union. Available from: http://www.eurosfaire.prd.fr/7pc/doc/1302102400_kk7911109enc_002. pdf [Accessed 25. January 2015].

Norwegian Ministry of Culture (2003). Kulturpolitikk fram mot 2014. Oslo: Kulturog kirkedepartementet. (Report no. 48 to the Storting (2002-2003).

Norwegian Ministry of Culture (2009). Libraries Knowledge Commons, Meeting Place and Cultural Arena in a Digital Age (Summary in English: Report No. 23 (2008-2009) to the Storting) Available from: https://www.regjeringen.no/conten tassets/6a7ad6f5ba584c8aafdc8bfa5cba86b1/en-gb/pdfs/stm200820090023000 en_pdfs.pdf [Accessed 25. October 2015]

Norwegian Ministry of Culture (2009a). National Strategy for Digital Preservation and Dissemination of Cultural Heritage (Summary in English: Report No. 24 (2008-2009) to the Storting) Available from: https:/www.regjeringen.no/contentassets/f3f0e538cc704abda770db1ef2c5399b/en-gb/pdfs/stm200820090024 000en_pdfs.pdf [Accessed 25. October 2015]

Primorac, J. \& Obuljen Koržinek, N. \& Uzelac, A. (2015) "Access to culture in Croatian cultural policy: Moving towards explicit policies”, International Journal of Cultural Policy, [Online first] DOI: 10.1080/10286632.2015.1102906

Primorac, J. and N. Obuljen Koržinek (2015) "National Report - Croatia”, pp. 165220. In: Access to culture - policy analysis: final report. Vienna: EDUCULT. [online]. Available from: http://educult.at/wp-content/uploads/2013/04/Final_ Report_Online_with-Annex.pdf [Accessed 21 September 2015]

Ratzenböck, V., Lungstraß, A., 2014. Compendium of cultural policies and trends in Europe - Austria. 15th edition 2014. Strasbourg: Council of Europe/ERICarts. Available from: http://www.culturalpolicies.net [Accessed 29 October 2015].

Righolt, N. (2015) Promoting access to culture via digital means: EENC AD hoc question. Available from: http://www.eenc.info/wp-content/themes/kingsize/images/upload/EENC-Promotionofaccesstocultureviadigitalmeans.pdf [Accessed 19 October 2015]

Russo, A.; Watkins, J.; Groundwater-Smith, S. (2009) "The impact of social media on informal learning in museums", Educational Media International, 46:2, 153166, DOI: 10.1080/09523980902933532

Throsby, D. (2010) The Economics of Cultural Policy. Cambridge University Press. UNESCO (1976) Recommendation on Participation by the People at Large in Cultural Life and their Contribution to It. Available from: http://portal.unesco.org/ en/ev.php-URL_ID=13097\&URL_DO=DO_TOPIC\&URL_SECTION=201. 
Medij. istraž. (god. 22, br. 1) 2016. (87-113)

html / http://unesdoc.unesco.org/images/0011/001140/114038e.pdf\#page=145 [14 October 2015]

Uzelac, A. (2004) "Digitalna kulturna dobra u informacijskom društvu između javne domene i privatnog vlasništva", Medijska istraživanja, Zagreb, Vol. 10, No. 1, 37-53

Uzelac, A. (2008) "How to understand digital culture: Digital culture - a resource for a knowledge society”, pp. 7-21. In: Uzelac, A.; Cvjetičanin, B. (eds): Digital Culture: The Changing Dynamics, Zagreb. IMO. Available from: http://www. culturelink.org/publics/joint/digicult/digital_culture-en.pdf [Accessed 21 January 2015]

Uzelac, A.; Obuljen Koržinek, N.; Primorac, J. (2015) "Digital Access: sharing or selling?", pp. 73-86. In: Access to culture - policy analysis: final report. Vienna: EDUCULT. [online]. Available from: http://educult.at/wp-content/uploads/2013 /04/Final_Report_Online_with-Annex.pdf [Accessed 21 September 2015]

Verbruggen, E. Oomen, J. (2012) D7.6.2 Online Access to Audiovisual Heritage Status Report, (Report on the project EUSCREEN Exploring Europe's Television Heritage in Changing Contexts) [online]. Available from: http://pro.europeana.eu/files/Europeana_Professional/Projects/Project_list/EUscreen/Deliverables/EUscreen\%20D7.6.2\%20OnlineAccesstoAudiovisualHeritageStatusReport.pdf [Accessed 21 January 2015].

Villarroya, A., Ateca-Amestoy, V., 2015. Compendium of cultural policies and trends in Europe - Spain. 17th edition 2015. Strasbourg: Council of Europe/ ERICarts. Available from: http://www.culturalpolicies.net [Accessed 29 October 2015].

\section{WEB SITES}

Digisam http://www.digisam.se

Europeana http://www.europeana.eu/

Europeana Professional http://pro.europeana.eu/

Europeana Labs http://labs.europeana.eu/

Internet World Stats http://www.internetworldstats.com/

(http://www.internetworldstats.com/europa.htm, accessed on 5th February 2015)

Kulturpool http://www.kunstkultur.bka.gv.at/site/cob_55658/8073/default.aspx

MUSEUM ONLINE http://www.museumonline.at/

Rijksstudio https://www.rijksmuseum.nl/en/rijksstudio 


\title{
Pristup kulturi u digitalnom prostoru: aktivni korisnici, ponovno korištenje sadržaja i kulturne politike
}

\author{
Aleksandra Uzelac \\ Nina Obuljen Koržinek \\ Jaka Primorac
}

\section{SAŽETAK}

Pitanja vezana uz pristup kulturi ušla su u fokus kulturnih politika s ciljem da doprinesu kulturnom razvoju, kvaliteti života građana, društvenoj uključenosti, i sl., pri čemu su razmatrane i mogućnosti koje digitalni prostor pruža kulturnom sektoru za omogućavanje pristupa kulturnom sadržaju. Pitanja pristupa kulturi u digitalnom kontekstu podrazumijevaju aspekte vezane uz uklanjanje prepreka pristupu kulturnim resursima kao i poticanje i promicanje mogućnosti građana za participaciju u kulturi. Koncept se definira kao dinamičan društveni proces, a ne kao jednostavno infrastrukturno omogućavanje pristupa. Pristup kulturnim resursima u digitalnom kontekstu suočava nas sa novim mogućnostima i preprekama na koje kulturne politike moraju adekvatno odgovoriti kako bi potakle razvoj digitalne kulture. U članku su analizirani pristupi eksplicitnih i implicitnih kulturnih politika u reguliranju digitalne kulture koji predstavljaju relevantan okvir koji omogućuje da kulturni sadržaji stignu do korisnika. Opisani su izazovi koje digitalni kontekst predstavlja za pitanja pristupa kulturnom sadržaju te su analizirani aspekti kulturnih politika koji razmatraju a) prava korisnika na korištenje kulturnog sadržaja te b) postojeću regulativu koja se odnosi na intelektualno vlasništvo i pravo na ponovno korištenje sadržaja jer takva regulativa omogućuje ili ograničava digitalne usluge koje kulturni sektor može pružiti građanima. U drugom dijelu članka predstavljeni su rezultati istraživanja projekta 'Pristupi kulturi - Analiza javnih politika' te su analizirani pristupi kulturnim politikama u reguliranju digitalnog pristupa kulturi u šest odabranih zemalja (Austrija, Hrvatska, Norveška, Španjolska, Švedska i Turska). Istraživanje je provedeno s ciljem da se omogući dublji uvid u pitanja vezana za digitalni pristup kulturi kako bi kulturne politike mogle adekvatno odgovoriti na izazove koji proizlaze iz digitalnog konteksta.

Ključne riječi: pristup kulturi, participacija korisnika, digitalna kultura, ponovno korištenje sadržaja, kulturna politika, javna politika 